\title{
Development of Processes for Recombinant L-Asparaginase II Production by Escherichia coli B121 (De3): From Shaker to Bioreactors
}

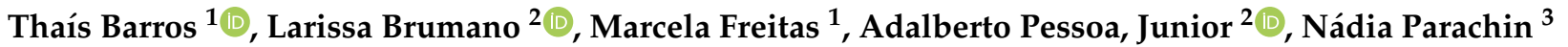 \\ and Pérola O. Magalhães ${ }^{1, * \mathbb{D}}$ \\ 1 Department of Pharmacy, Health Sciences School, University of Brasília, Brasília 70910-900, Brazil; \\ thaisousabarros@hotmail.com (T.B.); marcelafreitas@aluno.unb.br (M.F.) \\ 2 Department of Biochemical and Pharmaceutical Technology, University of São Paulo, \\ São Paulo 05508-000, Brazil; larissabrumano@usp.br (L.B.); pessoajr@usp.br (A.P.J.) \\ 3 Department of Cell Biology, Institute of Biology, University of Brasília, Brasília 70910-900, Brazil; \\ nadiasp@unb.br \\ * Correspondence: perolamagalhaes@unb.br
}

Citation: Barros, T.; Brumano, L.; Freitas, M.; Pessoa, A., Junior; Parachin, N.; Magalhães, P.d.O. Development of Processes for Recombinant L-Asp araginase II Production by Escherichia coli Bl21 (De3): From Shaker to Bioreactors. Pharmaceutics 2021, 13, 14. https://dx.doi.org/10.3390/ pharmaceutics13010014

Received: 3 November 2020 Accepted: 27 November 2020 Published: 24 December 2020

Publisher's Note: MDPI stays neutral with regard to jurisdictional claims in published maps and institutional affiliations.

Copyright: $\odot 2020$ by the authors. Licensee MDPI, Basel, Switzerland. This article is an open access article distributed under the terms and conditions of the Creative Commons Attribution (CC BY) license (https: / / creativecommons.org/ licenses/by/4.0/).

\begin{abstract}
Since 1961, L-asparaginase has been used to treat patients with acute lymphocytic leukemia. It rapidly depletes the plasma asparagine and deprives the blood cells of this circulating amino acid, essential for the metabolic cycles of cells. In the search for viable alternatives to produce L-asparaginase, this work aimed to produce this enzyme from Escherichia coli in a shaker and in a $3 \mathrm{~L}$ bioreactor. Three culture media were tested: defined, semi-defined and complex medium. L-asparaginase activity was quantified using the $\beta$-hydroxamate aspartic acid method. The defined medium provided the highest L-asparaginase activity. In induction studies, two inducers, lactose and its analog IPTG, were compared. Lactose was chosen as an inducer for the experiments conducted in the bioreactor due to its natural source, lower cost and lower toxicity. Batch and fed-batch cultures were carried out to reach high cell density and then start the induction. Batch cultivation provided a final cell concentration of $11 \mathrm{~g} \mathrm{~L}^{-1}$ and fed-batch cultivation produced $69.90 \mathrm{~g} \mathrm{~L}^{-1}$ of cells, which produced a volumetric activity of $43,954.79 \mathrm{U} \mathrm{L}^{-1}$ after lactose induction. L-asparaginase was produced in a shaker and scaled up to a bioreactor, increasing 23-fold the cell concentration and thus, the enzyme productivity.
\end{abstract}

Keywords: L-asparaginase; Escherichia coli; IPTG; lactose; shaker; bioreactor

\section{Introduction}

Acute Lymphocytic Leukemia (ALL) is a neoplasia with the highest incidence in children, representing $76 \%$ of leukemia cases in patients under 15 years of age [1]. This neoplasm is characterized by the uncontrolled proliferation of immature lymphocytes (blasts), preventing the bone marrow to function normally [2]. Since 1961, the enzyme L-asparaginase (L-ASNase) combined with danorubicin, vincristine and prednisolone is used in the treatment of ALL, with a survival rate of $80 \%$ in pediatric patients [3].

L-ASNase (L-asparagine aminohydrolase, EC 3.5.1.1) catalyzes the hydrolysis of the amino acid asparagine into aspartic acid and ammonia [4]. This enzyme has been widely used in the food and pharmaceutical industries. In the food industry, L-ASNase is used to reduce the formation of acrylamide that is produced when foods rich in starch are cooked or fried through the Maillard reaction $[5,6]$.

In the pharmaceutical field, L-ASNase is administered intravenously or intramuscularly, aiming at the rapid depletion of plasma asparagine (ASN), followed by the efflux of intracellular ASN depriving the cells of this circulating amino acid [7,8]. ASN is used in the metabolic cycles of the cell, and in its absence, the cell goes into apoptosis. However, unlike normal cells, cancer cells do not have or have low expression of the enzyme asparagine 
synthetase, being dependent on plasma ASN. Therefore, leukemic cells die of ASN starvation after depletion in plasma due to L-ASNase [7]. However, therapy with L-ASNase can cause significant effects such as anaphylaxis, coagulation abnormality, thrombosis, liver dysfunction, pancreatitis, hyperglycemia and cerebral dysfunction. These effects are due to the production of anti-asparaginase antibodies or by the glutaminase activity intrinsic to some L-ASNases [9].

In clinical practice, L-ASNase from two prokaryotic microorganisms are used, Escherichia coli and Dickeya dadantii (previously named as Erwinia chrysanthemi). E. coli LASNase formulations are used as line first treatment and E. chrysanthemi L-ASNase is used as second line treatment $[8,10,11]$.

In the process of developing a product's production, it is necessary to find suitable conditions that allow economically viable productivity and protein yield [12,13]. A combination of the production of recombinant proteins and large-scale processes has enabled the production of enzymes in greater quantities than found from their natural sources [14]. There is a wide variety of expression systems for the production of proteins, among them are cell cultures of bacteria, yeasts, fungi, mammals, plants, insects, transgenic and in vitro animals [15]. The E. coli is one of the most used hosts for the production of non-glycosylated heterologous because it presents advantages such as well-elucidated genetics and physiology, rapid growth, low cost of culture medium and allows high levels of protein expression enabling production and higher production scales [16,17]. For these advantages, E. coli was the expression system chosen for this work.

Aiming at the scarcity of studies on the production of recombinant L-ASNase in bioreactors, this work sought the production of this enzyme in a shaker and in high cell density in bioreactors up to $3 \mathrm{~L}$, in order to define a detailed process for the production of L-ASNase in E. coli BL 21 (DE3).

\section{Materials and Methods}

\subsection{Reagents}

The reagents used were Ampicillin, $\mathrm{Al}_{2}\left(\mathrm{SO}_{4}\right)_{3} \cdot 16 \mathrm{H}_{2} \mathrm{O}$, thiamine $\cdot \mathrm{HCl}, \mathrm{ZnSO} \mathrm{CH}_{4} \cdot 7 \mathrm{H}_{2} \mathrm{O}$, IPTG, Tris, hydroxylamine hydrochloride, Asparagine, $\mathrm{FeCl}_{3}, \mathrm{TCA}$ and L-aspartic acid $\beta$ hydroxamate were Sigma-Aldrich ${ }^{\mathrm{TM}}$ (Steinheim, NW, Germany). The reagents $\mathrm{KH}_{2} \mathrm{PO}_{4}$, citric acid, $\mathrm{MgSO}_{4} \cdot 7 \mathrm{H}_{2} \mathrm{O}, \mathrm{K}_{2} \mathrm{HPO}_{4}, \mathrm{ZnCl}_{2}, \mathrm{CaCl}_{2} \cdot 2 \mathrm{H}_{2} \mathrm{O}, \mathrm{CuSO}_{4} \cdot 5 \mathrm{H}_{2} \mathrm{O}, \mathrm{FeSO}_{4} \cdot 7 \mathrm{H}_{2} \mathrm{O}, \mathrm{NH}_{4} \mathrm{OH}$, $\mathrm{HCl}$ and lactose were Vetec Quimica Fina ${ }^{\mathrm{TM}}$ (Duque de Caxias, RJ, Brazil). The reagents glucose, $\left(\mathrm{NH}_{4}\right)_{2} \mathrm{HPO}_{4}, \mathrm{MnCl}_{2} \cdot 4 \mathrm{H}_{2} \mathrm{O}, \mathrm{Zn}\left(\mathrm{CH}_{3} \mathrm{COO}\right)_{2} \cdot \mathrm{H}_{2} \mathrm{O}, \mathrm{CoCl}_{2} \cdot 6 \mathrm{H}_{2} \mathrm{O}, \mathrm{CuCl}_{2} \cdot 2 \mathrm{H}_{2} \mathrm{O}$, EDTA $\cdot \mathrm{Na}_{2}, \mathrm{MnSO}_{4} \cdot \mathrm{H}_{2} \mathrm{O}, \mathrm{NiSO}_{4} \cdot 6 \mathrm{H}_{2} \mathrm{O}$, Acetate and $\mathrm{H}_{2} \mathrm{SO}_{4}$ were Dinâmica Quimica ${ }^{\mathrm{TM}}$ (Indaíatuba, SP, Brazil). The reagents tryptone was Acumedia ${ }^{\mathrm{TM}}$, yeast extract was Kasvi ${ }^{\mathrm{TM}}$ (São José dos Pinhais, PR, Brazil), sodium chloride was Cromoline ${ }^{\mathrm{TM}}$ (Diadema, SP, Brazil), Glycerol was PlusOne ${ }^{\mathrm{TM}}$, Iron (III) Citrate was Exxodo científica ${ }^{\mathrm{TM}}$ (Sumaré, SP, Brazil), $\mathrm{H}_{3} \mathrm{BO}_{3}$ was Quimex ${ }^{\mathrm{TM}}$ (Uberaba, MG, Brazil), $\mathrm{Na}_{2} \mathrm{MoO}_{4} \cdot 2 \mathrm{H}_{2} \mathrm{O}$ was Merck ${ }^{\mathrm{TM}}$ (Darmstadt, Germany) and $\mathrm{NaH}_{2} \mathrm{PO}_{4} \cdot \mathrm{H}_{2} \mathrm{O}$ was labsynth ${ }^{\mathrm{TM}}$ (Diadema, SP, Brazil).

\subsection{Microorganism}

The experiments were performed using E. coli BL 21 (DE3) strain as host, kindly provided by Dr. Gisele Monteiro from the Faculty of Pharmaceutical Sciences of University of São Paulo. The expression vector used was pET-15b, which contains a codon gene optimized for expression of E. coli L-ASNase (GenBank KY305877), an export signal sequence to the periplasmic space and ampicillin resistance gene as a selective marker.

The standard stock was prepared by inoculating isolate colonies into a $250 \mathrm{~mL}$ Erlenmeyer flask with $50 \mathrm{~mL}$ of Luria Bertani (LB) medium $\left(10.00 \mathrm{~g} \mathrm{~L}^{-1}\right.$ of tryptone; $5.00 \mathrm{~g} \mathrm{~L}^{-1}$ of yeast extract; $5.00 \mathrm{~g} \mathrm{~L}^{-1}$ of sodium chloride and $0.10 \mathrm{~g} \mathrm{~L}^{-1}$ of ampicillin). This was incubated in an orbital shaker (New Brunswick series Innova 44 incubator, Eppendorf AG, Germany) at $37^{\circ} \mathrm{C}$ and $180 \mathrm{rpm}$ until the optical density at $600 \mathrm{~nm}\left(\mathrm{OD}_{600 \mathrm{~nm}}\right)$ achieved values between 1.5 and 2.0. After centrifugation at $10,000 \times \mathrm{g}$ for $10 \mathrm{~min}$, the cells were sus- 
pended in $40 \mathrm{~mL}$ cryopreservation medium (85\% LB medium and 15\% glycerol). Aliquots were stored in cryotubes at $-80^{\circ} \mathrm{C}$.

\subsection{Culture Medium}

For the production of $\mathrm{L}-\mathrm{ASN}$ ase, three culture media were evaluated: the defined medium [18], the semi-defined medium [19] and the complex medium [20]. The composition of the defined medium was $5.00 \mathrm{~g} \mathrm{~L}^{-1}$ of glucose; $13.30 \mathrm{~g} \mathrm{~L}^{-1}$ of $\mathrm{KH}_{2} \mathrm{PO}_{4} ; 4.00 \mathrm{~g} \mathrm{~L}^{-1}$ of $\left(\mathrm{NH}_{4}\right)_{2} \mathrm{HPO}_{4} ; 1.70 \mathrm{~g} \mathrm{~L}^{-1}$ of citric acid; $1.20 \mathrm{~g} \mathrm{~L}^{-1}$ of $\mathrm{MgSO}_{4} \cdot 7 \mathrm{H}_{2} \mathrm{O} ; 0.06 \mathrm{~g} \mathrm{~L}^{-1}$ of Iron (III) Citrate; $1.50 \times 10^{-2} \mathrm{~g} \mathrm{~L}^{-1}$ of $\mathrm{MnCl}_{2} \cdot 4 \mathrm{H}_{2} \mathrm{O} ; 0.80 \times 10^{-2} \mathrm{~g} \mathrm{~L}^{-1}$ of $\mathrm{Zn}\left(\mathrm{CH}_{3} \mathrm{COO}\right)_{2} \cdot \mathrm{H}_{2} \mathrm{O}$; $0.30 \times 10^{-2} \mathrm{~g} \mathrm{~L}^{-1}$ of $\mathrm{H}_{3} \mathrm{BO}_{3} ; 0.25 \times 10^{-2} \mathrm{~g} \mathrm{~L}^{-1}$ of $\mathrm{Na}_{2} \mathrm{MoO}_{4} \cdot 2 \mathrm{H}_{2} \mathrm{O} ; 0.25 \times 10^{-2} \mathrm{~g} \mathrm{~L}^{-1}$ of $\mathrm{CoCl}_{2} \cdot 6 \mathrm{H}_{2} \mathrm{O} ; 0.15 \times 10^{-2} \mathrm{~g} \mathrm{~L}^{-1}$ of $\mathrm{CuCl}_{2} \cdot 2 \mathrm{H}_{2} \mathrm{O} ; 0.84 \times 10^{-2} \mathrm{~g} \mathrm{~L}^{-1}$ of EDTA $\cdot \mathrm{Na}_{2} ; 0.45 \times$ $10^{-2} \mathrm{~g} \mathrm{~L}^{-1}$ of thiamine.HCl. The composition of the semi-defined medium was $5.00 \mathrm{~g} \mathrm{~L}^{-1}$ of glucose; $1.00 \mathrm{~g} \mathrm{~L}^{-1}$ yeast extract; $13.00 \mathrm{~g} \mathrm{~L}^{-1}$ of $\mathrm{KH}_{2} \mathrm{PO}_{4} ; 10.00 \mathrm{~g} \mathrm{~L}^{-1}$ of $\mathrm{K}_{2} \mathrm{HPO}_{4}$; $3.00 \mathrm{~g} \mathrm{~L}^{-1}$ of $\left(\mathrm{NH}_{4}\right)_{2} \mathrm{HPO}_{4} ; 4.60 \mathrm{~g} \mathrm{~L}^{-1}$ of $\mathrm{NaH}_{2} \mathrm{PO}_{4} \cdot \mathrm{H}_{2} \mathrm{O} ; 2.00 \mathrm{~g} \mathrm{~L}^{-1}$ of $\mathrm{MgSO}_{4} \cdot 7 \mathrm{H}_{2} \mathrm{O} ; 8.10$ $\times 10^{-2} \mathrm{~g} \mathrm{~L}^{-1}$ of $\mathrm{FeCl}_{3} \cdot \mathrm{H}_{2} \mathrm{O} ; 0.39 \times 10^{-2} \mathrm{~g} \mathrm{~L}^{-1}$ of $\mathrm{ZnCl}_{2} ; 0.60 \times 10^{-2} \mathrm{~g} \mathrm{~L}^{-1}$ of $\mathrm{CoCl}_{2} \cdot 6 \mathrm{H}_{2} \mathrm{O}$; $7.38 \times 10^{-2} \mathrm{~g} \mathrm{~L}^{-1}$ of $\mathrm{CaCl}_{2} \cdot 2 \mathrm{H}_{2} \mathrm{O} ; 3.81 \times 10^{-3} \mathrm{~g} \mathrm{~L}^{-1}$ of $\mathrm{CuCl}_{2} \cdot 2 \mathrm{H}_{2} \mathrm{O} ; 0.15 \times 10^{-2} \mathrm{~g} \mathrm{~L}^{-1}$ of $\mathrm{H}_{3} \mathrm{BO}_{3} ; 0.48 \times 10^{-2} \mathrm{~g} \mathrm{~L}^{-1}$ of $\mathrm{Al}_{2}\left(\mathrm{SO}_{4}\right)_{3} \cdot 16 \mathrm{H}_{2} \mathrm{O} ; 2.04 \times 10^{-2} \mathrm{~g} \mathrm{~L}^{-1}$ of $\mathrm{MnSO}_{4} \cdot \mathrm{H}_{2} \mathrm{O}$; $0.60 \times 10^{-2} \mathrm{~g} \mathrm{~L}^{-1}$ of $\mathrm{Na}_{2} \mathrm{MoO}_{4} \cdot 2 \mathrm{H}_{2} \mathrm{O}$. And the composition of the complex medium was $5.00 \mathrm{~g} \mathrm{~L}^{-1}$ of glucose; $5.00 \mathrm{~g} \mathrm{~L}^{-1}$ yeast extract; $10.00 \mathrm{~g} \mathrm{~L}^{-1}$ of Tryptone; $10.00 \mathrm{~g} \mathrm{~L}^{-1}$ of $\mathrm{NaCl} ; 8.34 \mathrm{~g} \mathrm{~L}^{-1}$ of $\mathrm{KH}_{2} \mathrm{PO}_{4} ; 6.74 \mathrm{~g} \mathrm{~L}^{-1}$ of $\mathrm{K}_{2} \mathrm{HPO}_{4} ; 0.50 \mathrm{~g} \mathrm{~L}^{-1}$ of $\mathrm{MgSO}_{4} \cdot 7 \mathrm{H}_{2} \mathrm{O} ; 0.05 \mathrm{~g} \mathrm{~L}^{-1}$ of $\mathrm{CaCl}_{2} \cdot 2 \mathrm{H}_{2} \mathrm{O} ; 0.01 \times 10^{-2} \mathrm{~g} \mathrm{~L}^{-1}$ of $\mathrm{H}_{3} \mathrm{BO}_{3} ; 0.01 \times 10^{-2} \mathrm{~g} \mathrm{~L}^{-1}$ of $\mathrm{CoCl}_{2} \cdot 6 \mathrm{H}_{2} \mathrm{O} ; 2.50$ $\times 10^{-2} \mathrm{~g} \mathrm{~L}^{-1}$ of $\mathrm{ZnSO}_{4} \cdot 7 \mathrm{H}_{2} \mathrm{O} ; 0.4 \times 10^{-2} \mathrm{~g} \mathrm{~L}^{-1}$ of $\mathrm{MnCl}_{2} \cdot 4 \mathrm{H}_{2} \mathrm{O} ; 0.01 \times 10^{-2} \mathrm{~g} \mathrm{~L}^{-1}$ of $\mathrm{Na}_{2} \mathrm{MoO}_{4} \cdot 2 \mathrm{H}_{2} \mathrm{O} ; 0.18 \times 10^{-2} \mathrm{~g} \mathrm{~L}^{-1}$ of $\mathrm{CuSO}_{4} \cdot 5 \mathrm{H}_{2} \mathrm{O} ; 0.02 \mathrm{~g} \mathrm{~L}^{-1}$ of $\mathrm{FeSO}_{4} \cdot 7 \mathrm{H}_{2} \mathrm{O} ; 0.01 \times$ $10^{-2} \mathrm{~g} \mathrm{~L}^{-1}$ of $\mathrm{NiSO}_{4} \cdot 6 \mathrm{H}_{2} \mathrm{O}$. All media were supplemented with $0.10 \mathrm{~g} \mathrm{~L}^{-1}$ of ampicillin.

\subsection{Production of L-ASNase in Orbital Shaker}

The inoculum was prepared with $0.25 \mathrm{~mL}$ of the cell stock in a $250 \mathrm{~mL}$ Erlenmeyer flask containing $25 \mathrm{~mL}$ of the defined, semi-defined or complex medium supplemented with $0.10 \mathrm{~g} \mathrm{~L}^{-1}$ of ampicillin and incubated in the orbital shaker at $37^{\circ} \mathrm{C}$ and $180 \mathrm{rpm}$ for up to $16 \mathrm{~h}$.

Cultures were performed in an orbital shaker in $500 \mathrm{~mL}$ Erlenmeyer flasks containing $50 \mathrm{~mL}$ of the defined, semi-defined or complex medium with an initial $\mathrm{OD}_{600 \mathrm{~nm}}$ of 0.1. Aliquots of $0.50 \mathrm{~mL}$ were taken during the culture and the total volume removed was less than $10 \%$ of the initial volume. The cultures were performed in triplicates.

Two inducers were used in this work, lactose and the isopropyl analog $\beta$-D-1- thiogalactopyranoside (IPTG). The lactose stock solution was prepared at a concentration of $200 \mathrm{~g} \mathrm{~L}^{-1}$ in distilled water and sterilized by moist heat. The IPTG stock solution was prepared at a concentration of $1.00 \mathrm{~mol} \mathrm{~L}^{-1}$ in distilled water and sterilized by $0.22 \mu \mathrm{m}$ membrane filtration.

To determine the best concentration of each inductor, three concentrations were chosen based on previous studies. For IPTG, concentration often ranges from $0.10 \mathrm{mmol} \mathrm{L}^{-1}$ to $1.00 \mathrm{mmol} \mathrm{L}^{-1}$ [21-24] while lactose concentration varies from $10 \mathrm{~g} \mathrm{~L}^{-1}$ to $18 \mathrm{~g} \mathrm{~L}^{-1}$ [25-27]. Considering the reported concentrations, IPTG was evaluated at $0.10 \mathrm{mmol} \mathrm{L}^{-1}, 0.45 \mathrm{mmol}$ $\mathrm{L}^{-1}$ and $1.00 \mathrm{mmol} \mathrm{L}^{-1}$ and lactose was evaluated at $10 \mathrm{~g} \mathrm{~L}^{-1}, 14 \mathrm{~g} \mathrm{~L}^{-1}$ and $18 \mathrm{~g} \mathrm{~L}^{-1}$.

\subsection{Production of L-ASNase in Bioreactor}

For cultures in the bioreactor, the New Brunswick BioFlo/CelliGen ${ }^{\mathrm{TM}} 115$ bioreactor (Eppendorf AG, Hamburg, Germany) was used. Vessels with capacities of $1.30 \mathrm{~L}$ and $3.00 \mathrm{~L}$ were used for batch and fed-batches, respectively. The glucose concentration in the culture medium was adjusted to $27.50 \mathrm{~g} \mathrm{~L}^{-1}$. At $37^{\circ} \mathrm{C}, \mathrm{pH} 6.8$, it was not necessary to add acid, only base $\left(\mathrm{NH}_{4} \mathrm{OH} 3 \mathrm{M}\right)$. Dissolved oxygen (DO) was kept at a minimum of $40 \%$, by the agitation cascade of 200 to $900 \mathrm{rpm}$ and $2 \mathrm{vvm}$ of compressed air/oxygen were used during the process. 
Feeding started after the peak of dissolved oxygen (DO-stat), observed when the initial glucose consumption was completed. The composition of the feeding solution was $600.00 \mathrm{~g} \mathrm{~L}^{-1}$ of glucose, $20.00 \mathrm{~g} \mathrm{~L}^{-1}$ of $\mathrm{MgSO}_{4} \cdot 7 \mathrm{H}_{2} \mathrm{O}, 8.13 \times 10^{-1} \mathrm{~g} \mathrm{~L}^{-1}$ of EDTA, $0.04 \mathrm{~g} \mathrm{~L}^{-1}$ of Iron (III) citrate, $0.04 \times 10^{-1} \mathrm{~g} \mathrm{~L}^{-1}$ of $\mathrm{CoCl}_{2} \cdot 2 \mathrm{H}_{2} \mathrm{O}, 2.35 \times 10^{-2} \mathrm{~g} \mathrm{~L}^{-1}$ of $\mathrm{MnCl}_{2} \cdot 4 \mathrm{H}_{2} \mathrm{O}, 0.23 \times 10^{-2} \mathrm{~g} \mathrm{~L}^{-1}$ of $\mathrm{CuCl}_{2} \cdot 2 \mathrm{H}_{2} \mathrm{O}, 0.47 \times 10^{-2} \mathrm{~g} \mathrm{~L}^{-1}$ of $\mathrm{H}_{3} \mathrm{BO}_{3}, 0.04$ $\times 10^{-1} \mathrm{~g} \mathrm{~L}^{-1}$ of $\mathrm{Na}_{2} \mathrm{MoO}_{4} \cdot 2 \mathrm{H}_{2} \mathrm{O}$ and $0.16 \times 10^{-1} \mathrm{~g} \mathrm{~L}^{-1}$ of $\mathrm{Zn}\left(\mathrm{CH}_{3} \mathrm{COO}\right)_{2} \cdot \mathrm{H}_{2} \mathrm{O}$. The exponential feeding strategy was chosen to feed the cultivation, therefore it was necessary to obey the mathematical model derived from the mass balance assuming constant cellular yield [14]. Equation (1) is described below:

$$
F=\left(\frac{\mu}{Y_{x / s}}+m\right) X\left(t_{0}\right) V\left(t_{0}\right) \exp \left[\mu(\text { set })\left(t-t_{0}\right)\right]
$$

where, $F$ is the feed flow rate $\left(\mathrm{L} \mathrm{h}^{-1}\right) ; \mu$ is the actual specific growth rate $\left(\mathrm{h}^{-1}\right)$ and $\mu($ set $)$ the desired specific growth rate $\left(\mathrm{h}^{-1}\right) ; Y_{x / s}$ is the biomass/substrate coefficient $\left(\mathrm{g} \mathrm{g}^{-1}\right) ; m$ is the specific maintenance coefficient $\left(\mathrm{g} \mathrm{g}^{-1} \mathrm{~h}^{-1}\right) ; X\left(t_{0}\right)$ is the concentration of biomass at the beginning of feeding $\left(\mathrm{g} \mathrm{L}^{-1}\right) ; V$ is the cultivation volume at the beginning of feeding $(\mathrm{L})$ and $t-t_{0}$ is the feeding time elapsed $(\mathrm{h})$. The cultivations were performed in duplicates.

\subsection{L-asparaginase Activity Assay}

To quantify L-ASNase activity, the L-aspartyl- $\beta$-hydroxamate method (AHA) was employed, which measures the amount of L-aspartic acid $\beta$-hydroxamate released in the hydrolysis reaction catalyzed by the enzyme L-ASNase from the amino acid asparagine in the presence of hydroxylamine [28]. The assay was performed in $5 \mathrm{~mL}$ conical tubes. Test tubes were prepared by adding $1.50 \mathrm{~mL}$ of Tris-HCl buffer $\left(50.00 \mathrm{mmol} \mathrm{L}^{-1}\right.$, $\left.\mathrm{pH} 8.6\right)$, $0.20 \mathrm{~mL}$ of asparagine $\left(0.10 \mathrm{~mol} \mathrm{~L}^{-1}\right), 0.20 \mathrm{~mL}$ of hydroxalamine $\left(1.00 \mathrm{~mol} \mathrm{~L}^{-1}, \mathrm{pH} 7.0\right)$ and $0.05 \times 10^{-1} \mathrm{~g}$ of the sample. The sample blanks were prepared by adding $1.90 \mathrm{mLTris}$ $\mathrm{HCl}$ buffer $\left(50.00 \mathrm{mmol} \mathrm{L}^{-1}, \mathrm{pH} 8.6\right)$ to $0.05 \times 10^{-1} \mathrm{~g}$ of the sample and the tubes were incubated at $37^{\circ} \mathrm{C}$ for $30 \mathrm{~min}$. The reaction was stopped with $0.50 \mathrm{~mL}$ of ferric chloride reagent $\left(10 \%(w / v) \mathrm{FeCl}_{3}, 20 \%(w / v)\right.$ TCA and $0.66 \mathrm{M} \mathrm{HCl}$ solution). The tubes were centrifuged at $10,000 \times \mathrm{g}$ for $10 \mathrm{~min}$ and the absorbance of the supernatant was measured in a spectrophotometer at $500 \mathrm{~nm}$. The experiments were performed in independent biological triplicates and the activity of L-ASNase was quantified in triplicate. A standard curve was made with L-aspartic acid $\beta$-hydroxamate $(0.10,0.25,0.50,0.75,1.00,1.50,2.00$ and 3.00 $\mu \mathrm{mol})$ in Tris- $\mathrm{HCl}$ buffer $\left(50.00 \mathrm{mmol} \mathrm{L}^{-1}, \mathrm{pH} 8.6\right)$ with $0.50 \mathrm{~mL}$ of ferric chloride reagent, in triplicate. The equation of the line generated was $y=0.2967 x+0.0058$ with that of $R^{2}=$ 0.9957. L-ASNase activity was expressed as $\mathrm{U} \mathrm{g}^{-1}$ of wet cells in Equation (2).

$$
\frac{U}{g} L-\text { ASNase }=\left[\frac{(\mu \mathrm{mol} \mathrm{L}-\text { Aspartic acid } \beta-\text { hydroxamate })}{(\text { sample weight }(\mathrm{g})) \times(\text { reaction time }(\min ))}\right]
$$

Glucose, acetate and lactose were quantified using a Prominence UFLC ((Shimadzu ${ }^{\mathrm{TM}}$, Kyoto, Japan)) chromatograph equipped with SPD-20A (Shimadzu ${ }^{\text {TM}}$ ) and RID-10A $\left(\right.$ Shimadzu $\left.{ }^{\mathrm{TM}}\right)$ detectors. A Shim-Pack SCR-101H $\left(7.9 \mathrm{~mm} \times 30 \mathrm{~cm}\right.$, Shimadzu $\left.{ }^{\mathrm{TM}}\right)$ ion exclusion column was used. Samples were analyzed using $5.00 \mathrm{mmol} \mathrm{L}^{-1} \mathrm{H}_{2} \mathrm{SO}_{4}$ as a mobile phase in isocratic elution with a sample injection volume of $20.00 \mu \mathrm{L}, 0.60 \mathrm{~mL} / \mathrm{min}$ flow rate and column temperature of $60^{\circ} \mathrm{C}$.

\subsection{Determination of Cell Dry Weight}

For determination of cell dry weight, $2.00 \mathrm{~mL}$ conical tubes were used. The tubes were washed with distilled water and dried at $70{ }^{\circ} \mathrm{C}$ for $24 \mathrm{~h}$. After cooling to room temperature, they were weighed on an analytical scale. Aliquots $(1.00 \mathrm{~mL})$ of the cell culture $\left(\mathrm{OD}_{600 \mathrm{~nm}}=\right.$ $0.10,0.20,0.30,0.50,1.00,1.20,1.40)$ were transferred to the previously weighed tubes, in triplicate, centrifuged for $10 \mathrm{~min}$ at $10,000 \times \mathrm{g}$ and the cell pellet was washed with $2.00 \mathrm{~mL}$ of distilled water. Finally, the tubes were placed to dry in an oven at $70{ }^{\circ} \mathrm{C}$ up to constant 
weight. After plotting the $\mathrm{OD}_{600 \mathrm{~nm}}$ data versus cell dry weight, the equation of the line $\mathrm{y}=$ $1.7242 x+0.0745$ with that of $R^{2}=0.9902$ was obtained.

\subsection{Statistical Analysis}

Statistical analyses were performed using GraphPad Prism ${ }^{\mathrm{TM}}$ (San Diego, CA, U.S.A.) software version 6.01. Data distribution was assessed for normal distribution. For the data that presented normal distribution, it was applied a parametric test of variance analysis (ANOVA)-Dunnet, and the data were represented by the mean and standard deviation. The significant difference was considered for the values of $p \leq 0.05$.

\section{Results and Discussion}

\subsection{Assessment of the Culture Medium}

Three culture media were evaluated in shake flasks: the defined medium, the semidefined medium and the complex medium. The common carbon source among the three media, glucose, was fixed at $5.00 \mathrm{~g} \mathrm{~L}^{-1}$. For each medium, a growth curve was constructed and the final dry weight $(X)$, the specific growth rate $\left(\mu_{x}\right)$ and biomass yield $\left(Y_{x / s}\right)$ were calculated. The medium that presented the highest cellular growth after $10 \mathrm{~h}$ of cultivation was the complex medium with $3.24 \mathrm{~g} \mathrm{~L}^{-1}$, followed by the defined medium with $1.80 \mathrm{~g} \mathrm{~L}^{-1}$ and finally the semi-defined medium with $1.48 \mathrm{~g} \mathrm{~L}^{-1}$ (Table 1).

Table 1. Final dry weight $(X)$, specific growth rate $\left(\mu_{x}\right)$ and biomass yield $\left(Y_{x / s}\right)$ and L-ASNase activity of the defined, semi-defined and complex media. For the quantification of L-ASNase activity, cultivation was carried out in each culture medium with an $\mathrm{OD}_{600 \mathrm{~nm}}$ of $0.1,3 \mathrm{~h}$ after the beginning of the cultivation $0.45 \mathrm{mmol} \mathrm{L}^{-1}$ of IPTG was added and after $18 \mathrm{~h}$ of induction the cultivation was stopped and the activity quantified by the AHA method.

\begin{tabular}{ccccc}
\hline Medium & $\mathbf{X}\left(\mathbf{g ~ L}^{-\mathbf{1}}\right)$ & $\boldsymbol{\mu}_{\mathbf{x}}\left(\mathbf{h}^{-\mathbf{1}}\right)$ & $\mathbf{Y}_{\mathbf{x} / \mathbf{s}}\left(\mathbf{g ~ g}^{-\mathbf{1}}\right)$ & $\begin{array}{c}\text { L-ASNase Activity } \\
\left(\mathbf{U ~ g}_{\text {cell }} \mathbf{- 1}\right)\end{array}$ \\
\hline Defined & 1.80 & 0.55 & 0.31 & $94.77 \pm 10$ \\
Semi-defined & 1.48 & 0.70 & 0.40 & $39.00 \pm 10$ \\
Complex & 3.24 & 0.81 & 0.63 & $58.10 \pm 5$ \\
\hline
\end{tabular}

The highest $\mu_{\mathrm{x}}$ was achieved by the complex medium with $0.81 \mathrm{~h}^{-1}$ and the lowest $\mu_{\mathrm{x}}$ was found in the defined medium $\left(0.55 \mathrm{~h}^{-1}\right)$. The induction of the expression was performed by adding $0.45 \mathrm{mmol} \mathrm{L}^{-1}$ of IPTG, after three hours from the beginning of the cultivation. The culture was stopped after $18 \mathrm{~h}$ of induction. The highest enzyme activity was observed in the defined medium, with $94.77 \pm 10 \mathrm{U} \mathrm{g}_{\text {cell }}{ }^{-1}$, followed by the complex medium with $58.10 \pm 5 \mathrm{U} \mathrm{g}_{\text {cell }}{ }^{-1}$ and the semi-defined medium with the lowest L-ASNase activity of $39.00 \pm 10 \mathrm{U} \mathrm{g}_{\text {cell }^{-1}}$.

The $\mu_{x}$ was analyzed in the exponential phase of each medium. The complex medium presented the largest $\mu_{\mathrm{x}}$. It is known that there is a linear relationship between $\mu_{\mathrm{x}}$ and acetate production: the higher the $\mu_{x}$ the greater the acetate production $[29,30]$. The production of acetate must be controlled because in high concentrations acetate inhibits cell growth [31]. The complex medium presented the highest $Y_{x / s}$. The higher cellular concentration of the complex medium can be explained due to the fact that in addition to glucose, the complex medium has two more carbon sources, yeast extract and tryptone, thus causing the greatest cell growth. For the calculation of the $Y_{x / s}$, only glucose was considered as a carbon source. The presence of yeast extract and tryptone in the composition of the semi-defined and complex media brings the difficulty of reproduction as a disadvantage due to the significant variation of these compounds between batches and difficult quality control. The defined medium has been gaining ground in commercial fermentations due to its greater reproducibility and rapid scaling process [32]. Therefore, the defined medium was chosen for the continuity of the experiments. 


\subsection{Optimization of Induction Phase Using Shaker Flasks}

For the induction study, two inducers were compared, lactose and its analog, IPTG. The optimal inducer concentration, the ideal time to start induction and the ideal time to finish cultivation were determined for each inducer.

As it can be seen in Figure 1A, there was no significant difference in L-ASNase activity between IPTG concentrations of $0.45 \mathrm{mmol} \mathrm{L}^{-1}\left(112.81 \pm 10 \mathrm{U} \mathrm{g}_{\text {cell }}{ }^{-1}\right)$ and $1 \mathrm{mmol} \mathrm{L}^{-1}$ $\left(91.69 \pm 11 \mathrm{U} \mathrm{g}_{\text {cell }}{ }^{-1}\right)$. As demonstrated in Figure 1B, the lactose concentration that best induced L-ASNase production with a significant difference was $10 \mathrm{~g} \mathrm{~L}^{-1}$, with mean LASNase activity of $74.15 \pm 21 \mathrm{U} \mathrm{g}_{\text {cell }}{ }^{-1}$. The concentrations of $10 \mathrm{~g} \mathrm{~L}^{-1}$ and $0.45 \mathrm{mmol} \mathrm{L}^{-1}$ of lactose and IPTG, respectively, showed the highest L-ASNase activity values as demonstrated in Figure 1. Several studies used IPTG as an inducer for L-ASNase production (Table 2), with concentrations from 0.40 to $0.50 \mathrm{mmol} \mathrm{L}^{-1}$ being commonly used [33-36]. In previous studies, lactose was used at a concentration of $2 \mathrm{~g} \mathrm{~L}^{-1}$ reaching the specific activity $210 \mathrm{U} \mathrm{mg}^{-1}$ of the purified enzyme [37]. There is a difference in the final biomass concentration when comparing the cultivations induced with IPTG and lactose. The cultures induced with IPTG had an average final biomass of $1.92 \mathrm{~g} \mathrm{~L}^{-1}$ dry weight while the cultures induced with lactose had a final biomass of $2.67 \mathrm{~g} \mathrm{~L}^{-1}$ dry weight. This is due to fact that lactose serves as an inducer as well as a carbon source [25].

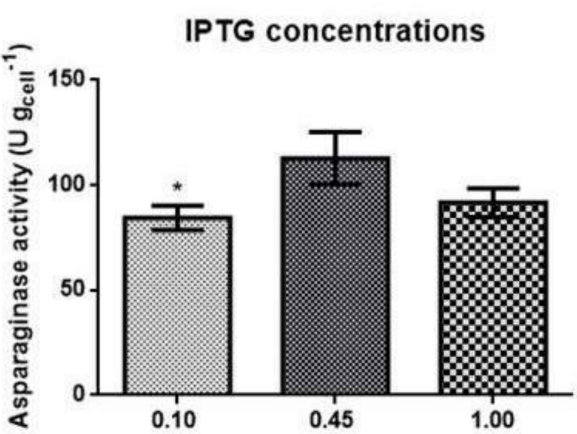

(A) IPTG concentrations $\left(\mathrm{mmol} \mathrm{L}^{-1}\right)$

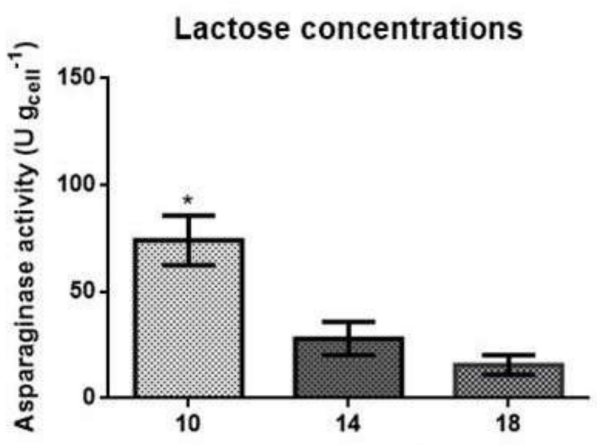

(B) Lactose concentrations $\left(\mathrm{g} \mathrm{L}^{-1}\right)$

Figure 1. Evaluation of L-asparaginase activity $\left(\mathrm{U} \mathrm{g}_{\text {cell }}{ }^{-1}\right)$ of recombinant E. coli cultivated with different inductor concentrations. In (A) three concentrations of IPTG $\left(0.10 \mathrm{mmol} \mathrm{L}^{-1}, 0.45 \mathrm{mmol} \mathrm{L}^{-1}\right.$ and $\left.1.00 \mathrm{mmol} \mathrm{L}^{-1}\right)$. were compared and expressed as $\mathrm{In}(\mathbf{B})$ three lactose concentrations $\left(10 \mathrm{~g} \mathrm{~L}^{-1}\right.$, $14 \mathrm{~g} \mathrm{~L}^{-1}$ and $18 \mathrm{~g} \mathrm{~L}^{-1}$ ) were compared. The results were expressed as mean and standard deviation. Cultivation was carried out in a defined medium, the initial $\mathrm{OD}_{600 \mathrm{~nm}}$ was 0.1 . After $5 \mathrm{~h}$ from the beginning of the cultivation, the inducer was added in different concentrations and after $24 \mathrm{~h}$ of induction the cultivation was stopped $\left({ }^{*}, p \leq 0.05\right)$.

L-ASNase activity was evaluated after cultivation in the defined medium at four time points: at the beginning of the exponential phase, $\mathrm{t}=3 \mathrm{~h}\left(\mathrm{OD}_{600 \mathrm{~nm}}\right.$ between 0.4 to 0.6$)$; middle of the exponential phase, $\mathrm{t}=5 \mathrm{~h}\left(\mathrm{OD}_{600 \mathrm{~nm}}\right.$ between 1.5 to 2.5$)$; at the end of the exponential phase, $\mathrm{t}=7 \mathrm{~h}\left(\mathrm{OD}_{600 \mathrm{~nm}} 3.8\right.$ to 4.0$)$ and finally in the stationary phase, $\mathrm{t}=9 \mathrm{~h}$ $\left(\mathrm{OD}_{600 \mathrm{~nm}} 4.1\right.$ to 4.6$)$. Cultivation was stopped after $24 \mathrm{~h}$ of induction.

As demonstrated in Figure 2A,B, the best time for L-ASNase production was in the middle of the exponential phase, after $5 \mathrm{~h}$ from the beginning of cultivation for both inducers. The culture induced with IPTG obtained L-ASNase activity of $115.99 \pm 7 \mathrm{U} \mathrm{g}_{\text {cell }^{-1}}{ }^{-1}$ while in lactose-induced cultivation an L-ASNase activity of $76.21 \pm 10 \mathrm{U} \mathrm{g}_{\text {cell }}{ }^{-1}$ was observed. Therefore, the exponential phase $(5 \mathrm{~h})$ was used as the time of induction in further experiments. Finally, L-ASNase activity was monitored between 10-24 h after induction. In Figure 2C, there was a plateau in L-ASNase activity of the IPTG-induced cultivation between $16-24 \mathrm{~h}$ with no statistical difference between them. In the lactoseinduced cultivations, the best L-ASNase activity values were found between $18 \mathrm{~h}$ and $20 \mathrm{~h}$, with no statistical difference between them. 
Table 2. Works published using Escherichia coli as an expression system for the production of L-asparaginase.

\begin{tabular}{|c|c|c|c|c|}
\hline Gene Origin & Médium & L-ASNase Activity & Inductor & Reference \\
\hline Pseudomonas resinovorans & Defined & $38.88 \mathrm{UI} \mathrm{mL}^{-1} \Delta$ & IPTG & {$[34]$} \\
\hline Anoxybacillus flavithermus & LB & $165 \mathrm{U} \mathrm{mg}^{-1 *} \mathrm{O}$ & IPTG & {$[38]$} \\
\hline Acinetobacter soli & LB & $400 \mathrm{U} \mathrm{mg}^{-1 *} \mathrm{O}$ & IPTG & [33] \\
\hline Thermococcus kodakarensis & LB & $767 \mathrm{U} \mathrm{mg}^{-1 *} \mathrm{O}$ & IPTG & [39] \\
\hline Cobetia amphilecti & LB & $778 \mathrm{U} \mathrm{mg}^{-1 *} \mathrm{O}$ & IPTG & {$[40]$} \\
\hline Lactobacillus casei & LB & $0.419 \mathrm{U} \mathrm{mg}^{-1} * \mathrm{O}$ & IPTG & {$[41]$} \\
\hline Bacillus sp & LB & - & IPTG & {$[35]$} \\
\hline Pyrobaculum calidifontis & - & $20.13 \mathrm{U} \mathrm{L}^{-1} \Delta$ & IPTG & {$[42]$} \\
\hline Vibrio cholerae & LB & $2120 \mathrm{U} \mathrm{mg}^{-1 * O}$ & IPTG & {$[43]$} \\
\hline Pseudomonas fluorescens & LB & $26 \mathrm{U} \mathrm{mg}^{-1} * \mathrm{O}$ & IPTG & {$[44]$} \\
\hline Aspergillus terréus & LB & $42.46 \mathrm{U} \mathrm{mg}^{-1} * \mathrm{O}$ & IPTG & {$[45]$} \\
\hline Halomonas elongata & LB & $1510 \mathrm{U} \mathrm{mg}^{-1 *} \mathrm{O}$ & IPTG & {$[46]$} \\
\hline Escherichia coli & LB & - & IPTG & [36] \\
\hline Paenibaeillus barengoltzii & LB & $35.2 \mathrm{U} \mathrm{mg}^{-1 *} \mathrm{O}$ & IPTG & [47] \\
\hline Synechococcus elongatus & LB & $45 \mathrm{U} \mathrm{mg}^{-1 *} \mathrm{O}$ & IPTG & {$[48]$} \\
\hline Saccharomyces cerevisiae & LB & $110.1 \mathrm{UI} \mathrm{mg}^{-1} * \mathrm{O}$ & IPTG & [49] \\
\hline Saccharomyces cerevisiae & LB & $196.2 \mathrm{U} \mathrm{mg}^{-1} * \mathrm{O}$ & IPTG & {$[50]$} \\
\hline Erwinia carotovora & LB & $12.5 \mathrm{U} \mathrm{mg}^{-1 *} \mathrm{O}$ & IPTG & [51] \\
\hline Mesoflavibacter zeaxanthinifaciens & LB & $687.1 \mathrm{U} \mathrm{mg}^{-1} * \mathrm{O}$ & IPTG & [52] \\
\hline Escherichia coli & Defined & $40.8 \mathrm{U} \mathrm{mL}^{-1 * \Delta}$ & IPTG & {$[53]$} \\
\hline Pseudomonas fluorescens & LB & $0.95 \mathrm{UI} \mathrm{mg}^{-1} * \mathrm{O}$ & IPTG & {$[54]$} \\
\hline Rhodospirillum rubrum & LB & $210 \mathrm{U} \mathrm{mg}^{-1 *} \mathrm{O}$ & Lactose & [37] \\
\hline Escherichia coli & LB & $190 \mathrm{U} \mathrm{mg}^{-1} * \mathrm{O}$ & IPTG & [55] \\
\hline Staphylococcus sp & LB & $113.06 \mathrm{U} \mathrm{mg}^{-1 * \mathrm{O}}$ & IPTG & {$[56]$} \\
\hline Erwinia carotovora & LB & $0.72 \mathrm{UI} \mathrm{mg}^{-1 * \Delta}$ & IPTG & [57] \\
\hline Erwinia carotovora & LB & $9.6 \mathrm{kcal} \mathrm{mol}^{-1} \mathrm{O}$ & IPTG & {$[58]$} \\
\hline Yersinia pseudotuberculosis & LB & - & Arabinose & [59] \\
\hline Yersinia Pseudotuberculosis & LB & $62.7 \mathrm{U} \mathrm{mg}^{-1 *} \mathrm{O}$ & Arabinose & {$[60]$} \\
\hline Withania somnifera $L$. & LB & $55 \mathrm{UI} \mathrm{mg}^{-1 *} \mathrm{O}$ & IPTG & {$[61]$} \\
\hline Yersinia pseudotuberculosis & LB & $62.7 \mathrm{UI} \mathrm{mg}^{-1} * \mathrm{O}$ & Arabinose & {$[62]$} \\
\hline Flammulina velutipes & LB & $16 \mathrm{U} \mathrm{mL}^{-1} \Delta$ & IPTG & {$[63]$} \\
\hline Glycine max & - & - & IPTG & [64] \\
\hline Escherichia coli & LB & $130 \mathrm{U} \mathrm{mL}^{-1} \Delta$ & - & {$[65]$} \\
\hline Erwinia carotovora & LB & $0.72 \mathrm{U} \mathrm{mg}^{-1 * \Delta}$ & IPTG & {$[66]$} \\
\hline Erwinia carotovora & LB & $630 \mathrm{UI} \mathrm{mg}^{-1} * \mathrm{O}$ & IPTG & {$[67]$} \\
\hline Escherichia coli AS1.357 & LB & $228 \mathrm{U} \mathrm{mL}^{-1} \Delta$ & Heat & {$[68]$} \\
\hline Escherichia coli & LB & $91 \mathrm{U} \mathrm{mg}^{-1 * O}$ & IPTG & {$[69]$} \\
\hline Escherichia coli & Defined & $1.08 \mathrm{U} \mathrm{mg}^{-1 * \Delta}$ & Lactose & This work \\
\hline
\end{tabular}




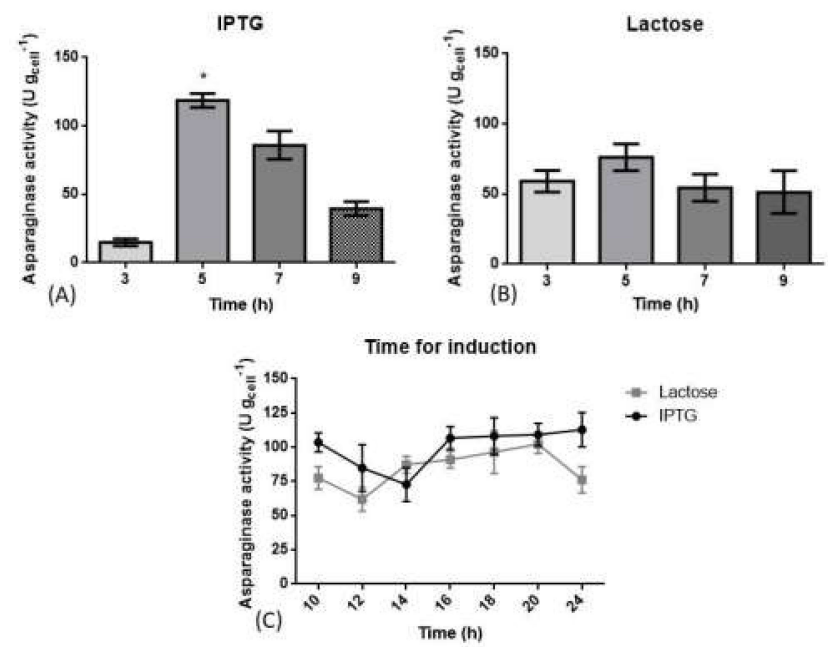

Figure 2. Study of L-ASNase production by recombinant E. coli induction with IPTG and lactose in a shaker. In (A), the induction was performed with IPTG varying the time of the beginning of the induction. In (B), the induction was performed with lactose, varying the induction start time. The cultures were induced in four moments, $3 \mathrm{~h}\left(\mathrm{OD}_{600 \mathrm{~nm}}\right.$ between 0.4 and 0.6$), 5 \mathrm{~h}\left(\mathrm{OD}_{600 \mathrm{~nm}}\right.$ between 1.5 and 2.5), $7 \mathrm{~h}\left(\mathrm{OD}_{600 \mathrm{~nm}}\right.$ between 3.8 and 4.0) and $9 \mathrm{~h}\left(\mathrm{OD}_{600 \mathrm{~nm}}\right.$ between 4.1 and 4.6). (C) is a comparison between lactose and IPTG enzyme activities within 10-24 h after induction. The black line represents the IPTG-induced cultivation and the gray line, the lactose-induced cultivations. The results of L-asparaginase activities $\left(\mathrm{U} \mathrm{g}_{\text {cell }}{ }^{-1}\right)$. The results expressed as mean and standard deviation $\left({ }^{*}, p \leq 0.05\right)$. The cultures were performed in a defined medium with the initial $\mathrm{OD}_{600 \mathrm{~nm}}$ of 0.1 and concentration of inducers being $0.45 \mathrm{mmol} \mathrm{L}^{-1}$ of IPTG and $10 \mathrm{~g} \mathrm{~L}^{-1}$ of lactose.

The best time to start induction for both studied inducers was $5 \mathrm{~h}$ after the start of the cultivation, in the middle of the exponential phase, as described in Figure 2A,B. In previous studies, the time chosen for induction was when the $\mathrm{OD}_{600 \mathrm{~nm}}$ was between 0.40 and $0.80[38,47,51-53]$. Since IPTG is toxic to cells, if added at the beginning of the cultivation there will be a loss in the final biomass concentration [27]. The interval of best L-ASNase activity was the same for both inducers used with no statistical difference between them. In the literature, is commonly found the induction ranged from 20 to $24 \mathrm{~h}$ after the start of cultivation [33,52,53].

Tian et al. (2011), compared the use of IPTG and lactose as inducers. The concentration of IPTG used was not described, and lactose with concentrations ranging from 2 to $50 \mathrm{~g} \mathrm{~L}^{-1}$ were evaluated for the production of keratinocyte growth factor-2. The highest production was achieved with $10 \mathrm{~g} \mathrm{~L}^{-1}$ of lactose, a result similar to that found in the present study [27]. Bashir et al. (2016), also reported a comparison between induction with IPTG and lactose, using IPTG concentrations of $1.00 \mathrm{mmol} \mathrm{L}^{-1}, 1.50 \mathrm{mmol} \mathrm{L}^{-1}$ and $2.50 \mathrm{mmol} \mathrm{L}^{-1}$ and lactose concentrations from 2 to $16 \mathrm{~g} \mathrm{~L}^{-1}$. The authors concluded that $14 \mathrm{~g} \mathrm{~L}^{-1}$ of lactose showed the same level of induction as the concentration of $1.50 \mathrm{mmol} \mathrm{L}^{-1}$ IPTG for the production of recombinant consensus interferon [25]. The use of lactose as an inducer has advantages and disadvantages. As advantages it is possible to consider that it is of natural source, it has low cost, low toxicity and has a low induction speed, which is a benefit for the production of more soluble proteins [25,27]. As a disadvantage, lactose acts as both an inducer and as a carbon source during fermentation, which makes the process more difficult to control and requires higher amount a in the process when compared to IPTG [25]. Therefore, future studies that consider technical-economic analysis are needed to confirm which inducer (IPTG or lactose) is more advantageous for a scale-up process since they did not present statistically significant differences in each respective optimal concentration in the present work. 


\subsection{Bioreactor Cultivation}

Initially, batch cultivation was performed in order to obtain the kinetic parameters of recombinant $E$. coli strain.

As shown in Figure 3A, the maximum biomass obtained was $11 \mathrm{~g} \mathrm{~L}^{-1}$. The cultivation was interrupted when the $\mathrm{OD}_{600 \mathrm{~nm}}$ started to decay. Glucose was completely consumed, and the residual acetate was $0.09 \mathrm{~g} \mathrm{~L}^{-1}$. The batch parameters are represented in Table 3.

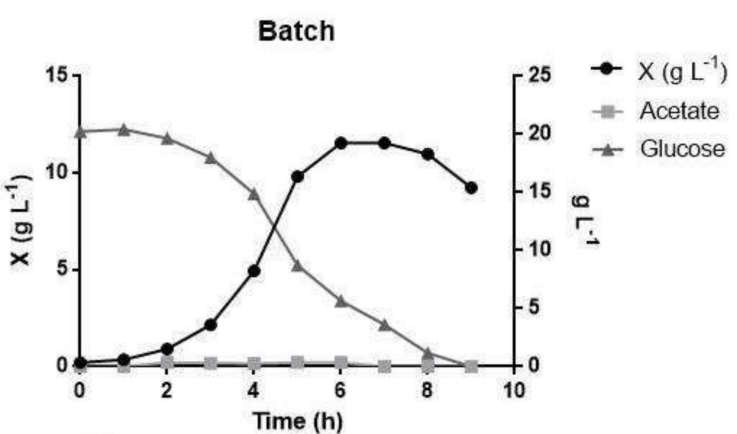

(A)

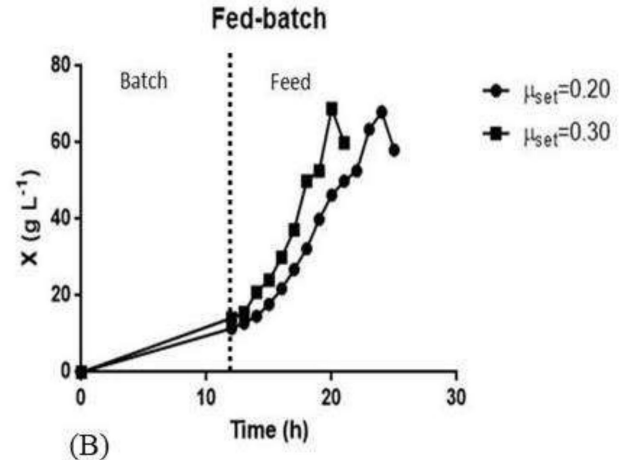

(B)

Figure 3. L-ASNase production of the recombinant E. coli cultivated in a bioreactor. (A) Batch cultivation. (B): Evaluation of $\mu_{\text {set }} 0.20 \mathrm{~h}^{-1}$ and $0.30 \mathrm{~h}^{-1}$ during exponential dry weight feeding (X). The experiments were carried out in biological duplicate and the figure shows a typical fermentation profile. The cultivations represented in (A) were carried out in a bioreactor with a capacity of $1.30 \mathrm{~L}$ and the initial $\mathrm{OD}_{600 \mathrm{~nm}}$ of 0.4 . The cultivations represented in $(\mathbf{B})$ were carried out in a bioreactor with a capacity of $3 \mathrm{~L}$ and an initial $\mathrm{OD}_{600 \mathrm{~nm}}$ of 0.01 . Cultivations were stopped when biomass decayed.

Table 3. Fermentation data of batch and fed-batch using recombinant $E$. coli. Specific growth rate $\left(\mu_{\mathrm{x}}\right)$, desired specific growth rate $\left(\mu_{\text {set }}\right)$, Max dry weight $\left(X_{\max }\right)$, biomass yield $\left(Y_{x / s}\right)$, glucose, acetate and residual lactose.

\begin{tabular}{|c|c|c|c|c|c|c|c|c|}
\hline \multicolumn{2}{|c|}{ Fermentation } & $\begin{array}{c}\mu_{x} \\
\left(h^{-1}\right)\end{array}$ & $\begin{array}{c}\mu_{\text {set }} \\
\left(h^{-1}\right)\end{array}$ & $\begin{array}{c}X_{\max } \\
\left(g^{-1} L^{-1}\right)\end{array}$ & $\begin{array}{c}Y_{\mathrm{X} / \mathrm{s}} \\
\left(\mathrm{g} \mathrm{L}^{-1}\right)\end{array}$ & $\begin{array}{c}\text { Glucose } \\
\left(\mathrm{g} \mathrm{L}^{-1}\right)\end{array}$ & $\begin{array}{l}\text { Acetate } \\
\left(\mathrm{g} \mathrm{L}^{-1}\right)\end{array}$ & $\begin{array}{l}\text { Lactose } \\
\left(\mathrm{g} \mathrm{L}^{-1}\right)\end{array}$ \\
\hline \multicolumn{2}{|c|}{ Batch } & 0.79 & - & 11.00 & 0.45 & - & 0.09 & - \\
\hline \multirow{2}{*}{ Batch fed } & - & - & 0.20 & 68.05 & 0.24 & 01.28 & 1.60 & - \\
\hline & - & - & 0.30 & 68.98 & 0.25 & 00.86 & 2.56 & - \\
\hline \multirow{3}{*}{$\begin{array}{c}\text { Induction } \\
\text { with } \\
\text { lactose }\end{array}$} & $10 \mathrm{~g} \mathrm{~L}^{-1}$ & - & 0.30 & 68.96 & 0.25 & 00.40 & 0.96 & 1.21 \\
\hline & $20 \mathrm{~g} \mathrm{~L}^{-1}$ & - & 0.30 & 58.09 & 0.21 & 01.06 & 0.60 & 1.04 \\
\hline & $30 \mathrm{~g} \mathrm{~L}^{-1}$ & - & 0.30 & 59.90 & 0.31 & 17.35 & 5.25 & 2.36 \\
\hline
\end{tabular}

In previous studies, where E. coli BL 21 was used for the production of peptide in the batch phase, the $\mu_{\mathrm{x}}$ of $0.74 \mathrm{~h}^{-1}$ was calculated and the acetate concentration was below $0.50 \mathrm{~g} \mathrm{~L}^{-1}$ using complex medium [26]. In another work, the biomass reached $12 \mathrm{~g} \mathrm{~L}^{-1}$ during the batch phase, a similar result to that found in the present study $\left(11 \mathrm{~g} \mathrm{~L}^{-1}\right)$ using the same culture medium. The acetate production in the article was $1 \mathrm{~g} \mathrm{~L}^{-1}$, higher than that found in the present work of $0.09 \mathrm{~g} \mathrm{~L}^{-1}$ [18].

Taking the control of production into consideration, two values of $\mu_{\text {set }}$ were evaluated for the fed-batch: $0.20 \mathrm{~h}^{-1}$ and $0.30 \mathrm{~h}^{-1}$. In Figure 3B, the growth of biomass, glucose consumption and acetate production during feeding is presented. The batch phase is represented from 0 to $12 \mathrm{~h}$. No samples were taken during this period since this phase was already well-described in the previous experiments of batch cultivations. After the DO peak, which represents the end of the initial glucose in the medium, feeding was started and samples were taken every hour. The maximum dry weight achieved was $69 \mathrm{~g} \mathrm{~L}^{-1}$, in both $\mu_{\text {set }}$, but at different times. Using $\mu_{\text {set }}$ of $0.30 \mathrm{~h}^{-1}$, the maximum biomass was reached with $8 \mathrm{~h}$ of feeding and using $\mu_{\text {set }}$ of $0.20 \mathrm{~h}^{-1}$, the maximum biomass was reached 
after $12 \mathrm{~h}$ of feeding. The residual acetate was $1.60 \mathrm{~g} \mathrm{~L}^{-1}$ and 2.56 at $\mu_{\text {set }}$ of $0.20 \mathrm{~h}^{-1}$ and $0.30 \mathrm{~h}^{-1}$, respectively, as described in Table 3. Oxygen was a limiting factor in both cultures. A mixture of $2 \mathrm{vvm}$ compressed air and pure oxygen was added. The proportion of this mixture was adjusted according to the need for fermentation, reaching $100 \%$ oxygen.

Seeking to maximize volumetric productivity, high cell density cultivations were carried out, which has the advantage of reduced volumes in reactors, reduced residual water, easier cell separation and better product yield [18,70]. To achieve high cell density, continuous feeding of substrates is necessary for the production of intracellular and extracellular products [71]. Exponential rate feeding was developed in order to control the specific growth rate through the feed rate. An advantage of this type of feeding is to keep it below the critical value of acetate formation. In E. coli fermentations, it is desirable to maintain a low concentration of acetate because, in high concentrations, acetate will inhibit the growth and production of recombinant proteins, being described that the ideal $\mu_{\text {set }}$ would be between $0.10 \mathrm{~h}^{-1}$ and $0.30 \mathrm{~h}^{-1}$ so that acetate production during feeding would not inhibit cell growth [14]. As shown in Figure 3B, in both cultures $\mu_{\text {set }}$ of $0.20 \mathrm{~h}^{-1}$ or $0.30 \mathrm{~h}^{-1}$, dry mass reached $69 \mathrm{~g} \mathrm{~L}^{-1}$.

Few studies have reported the use of bioreactors for the production of L-ASNase by $E$. coli. Mihooliya and collaborators (2020) reported the achievement of OD $_{600 \mathrm{~nm}} 6$ using a bioreactor with a capacity of $2 \mathrm{~L}$ and the cultivation was carried out in batch [34]. Roth and collaborators (2013) reached $30 \mathrm{~g} \mathrm{~L}^{-1}$ of dry weight using a bioreactor with a capacity of $2 \mathrm{~L}$ and the cultivation was carried out in fed-batch [58]. In a work published by Khushoo and collaborators (2005) the maximum biomass achieved was $53.30 \mathrm{~g} \mathrm{~L}^{-1}$ and the cultivation was carried out in fed-batch [72]. In the present work, a higher cell concentration of $69 \mathrm{~g} \mathrm{~L}^{-1}$ of dry cell weight $\left(\mathrm{OD}_{600 \mathrm{~nm}}\right.$ of 158$)$ was achieved during the fed-batch.

The study of lactose concentration for induction was performed with three concentrations: $10 \mathrm{~g} \mathrm{~L}^{-1}, 20 \mathrm{~g} \mathrm{~L}^{-1}$ and $30 \mathrm{~g} \mathrm{~L}^{-1}$. Induction was carried out when the cultivation reached $50 \mathrm{~g} \mathrm{~L}^{-1}$ dry weight and was interrupted when dry weight decay started. Figure $4 \mathrm{~A}$ shows the comparison of the three growth curves that were induced with different concentrations of lactose, and Figure $4 \mathrm{~B}$ shows the L-ASNase activity in $\mathrm{Ug}_{\text {cell }}{ }^{-1}$. The culture that was induced with $10 \mathrm{~g} \mathrm{~L}^{-1}$ of lactose was the one with the highest cell concentration $\left(69 \mathrm{~g} \mathrm{~L}^{-1}\right)$ but presented the lowest L-ASNase activity $\left(11.79 \pm 0.53 \mathrm{U} \mathrm{g}_{\text {cell }}{ }^{-1}\right)$. The culture that was induced with $20 \mathrm{~g} \mathrm{~L}^{-1}$ achieved a maximum cell concentration of $58 \mathrm{~g} \mathrm{~L}^{-1}$ and an increase in the value of L-ASNase activity $\left(22.56 \pm 0.93 \mathrm{U} \mathrm{g}_{\text {cell }}{ }^{-1}\right)$. Finally, the culture that was induced with $30 \mathrm{~g} \mathrm{~L}^{-1}$ of lactose had a maximum cell concentration of $59 \mathrm{~g} \mathrm{~L}^{-1}$ and the highest L-ASNase activity $\left(41.68 \pm 10 \mathrm{U} \mathrm{g}_{\text {cell }}{ }^{-1}\right)$.

Studies of lactose induction in a bioreactor were necessary due to the increase in cell concentration at the time of induction compared to culture in shaker flasks. The cultivation was induced with lactose in concentrations of 10, 20 and $30 \mathrm{~g} \mathrm{~L}^{-1}$. As shown in Figure 4A, less cell concentration was achieved in the cultures that used 20 and $30 \mathrm{~g} \mathrm{~L}^{-1}$ of lactose as an inducer, which can be attributed to the low solubility of lactose. Lactose has a solubility of $216 \mathrm{~g} \mathrm{~L}^{-1}$, thus requiring an increasing volume to reach the desired concentration in the culture. However, increased volume resulted in the dilution of the culture. Vélez et al. used pulses of $400 \mathrm{~mL}$ of lactose $\left(200 \mathrm{~g} \mathrm{~L}^{-1}\right)$ to induce the culture, to circumvent the low solubility of lactose for the production of Penicillin $\mathrm{G}$ acylase with maximum enzyme productivity of $7800 \mathrm{IU} \mathrm{L}{ }^{-1} \mathrm{~h}^{-1}$ [73].

In Figure 4B, cultivation with lactose as an inducer at $30 \mathrm{~g} \mathrm{~L}^{-1}$ concentration provided the highest level of L-ASNase activity, the highest amount of unconsumed glucose and the highest production of acetate at the end of the cultivation in comparison to the other lactose concentrations used for induction, as shown in Figure 5 and in Table 3. This result could be explained by the hydrolysis of lactose in glucose and galactose, thus increasing the glucose concentration in the culture medium, thus excess glucose can explain the increase in acetate production. Furthermore, the reduction of the growth rate at this cultivation could be explained by the high concentration of acetate [31,74]. 


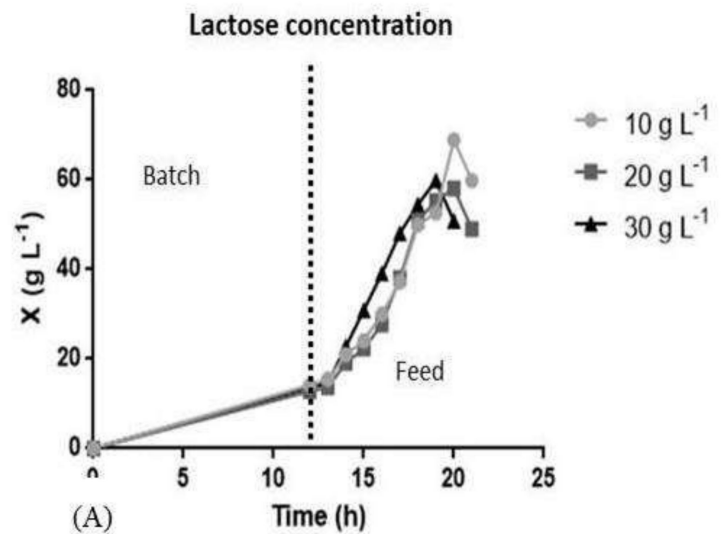

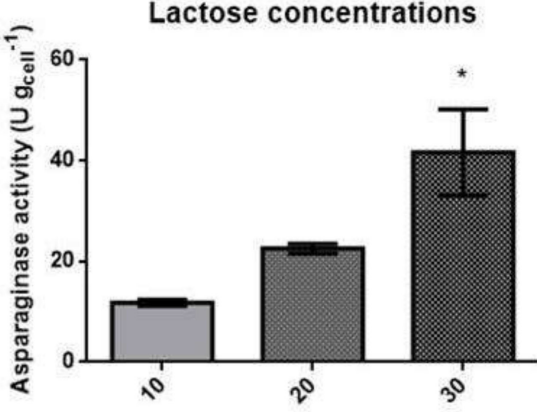

(B) Lactose concentrations $\left(\mathrm{g} \mathrm{L}^{-1}\right)$

Figure 4. Study of induction of L-ASNase production by recombinant $E$. coli in a bioreactor with three concentrations of lactose $\left(10 \mathrm{~g} \mathrm{~L}^{-1}, 20 \mathrm{~g} \mathrm{~L}^{-1}\right.$ and $\left.30 \mathrm{~g} \mathrm{~L}^{-1}\right)$. (A) shows the three growth curves in dry weight $\left(\mathrm{g} \mathrm{L}^{-1}\right)(\mathrm{X})$ and $(\mathbf{B})$ shows the enzyme activity obtained by the different lactose concentrations used for induction. The experiments were carried out in biological duplicate and the figure shows a typical fermentation profile. The results of L-asparaginase activities $\left(\mathrm{U} \mathrm{g}_{\text {cell }}{ }^{-1}\right)$ were expressed as mean and standard deviation $\left.{ }^{*}, p \leq 0.05\right)$. Cultures were performed in a $3.00 \mathrm{~L}$ bioreactor with an initial $\mathrm{OD}_{600 \mathrm{~nm}}$ of 0.01 in a defined medium. Cultures were induced when cell concentration reached $50 \mathrm{~g} \mathrm{~L}^{-1}$ and cultivation occurred when cell concentration declined.

Lactose $10 \mathrm{~g} \mathrm{~L}^{-1}$

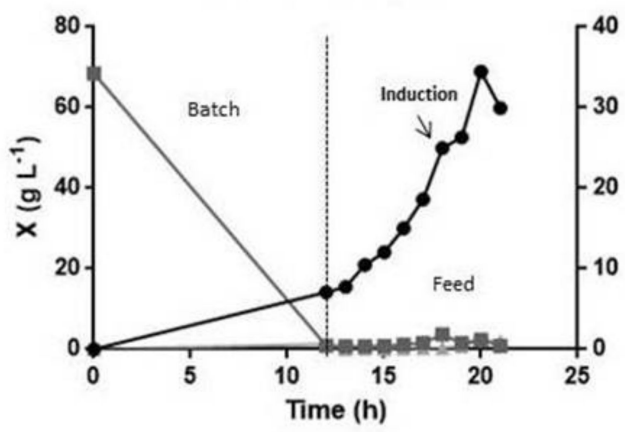

Lactose $20 \mathrm{~g} \mathrm{~L}^{-1}$

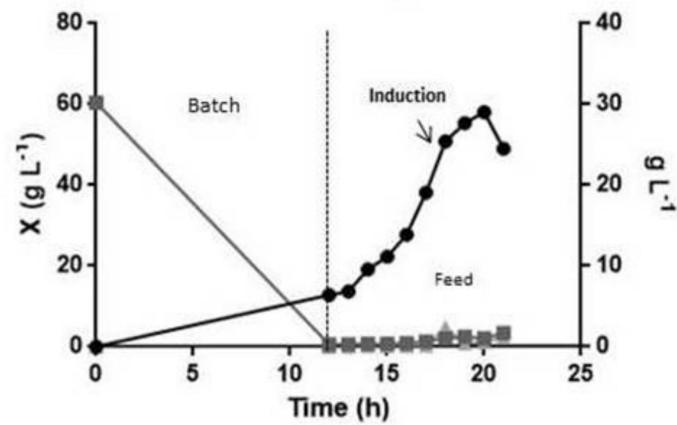

\section{Lactose $30 \mathrm{~g} \mathrm{~L}^{-1}$}

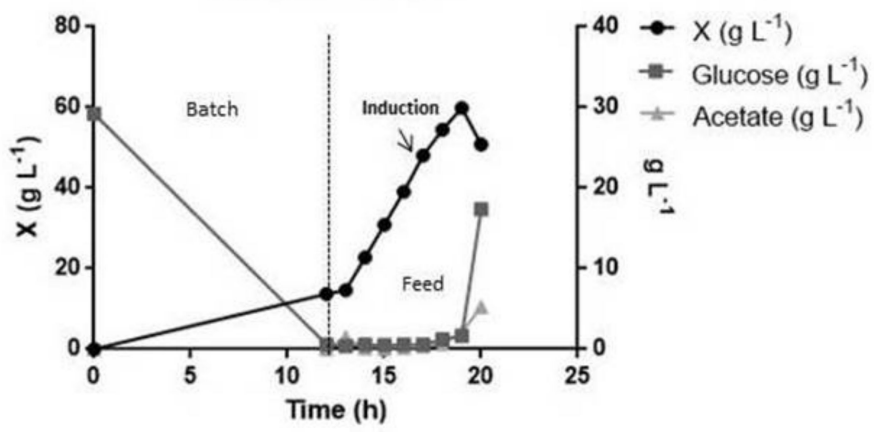

Figure 5. Representation of biomass growth, glucose consumption and acetate production in cultivations with different lactose concentrations. The ball represents the biomass $\left(\mathrm{g} \mathrm{L}^{-1}\right)$, the quadrate the glucose consumption $\left(\mathrm{g} \mathrm{L}^{-1}\right)$, the triangle the acetate production $\left(\mathrm{g} \mathrm{L}^{-1}\right)$ and the arrow represents the moment of lactose induction. Cultures were performed in a $3.00 \mathrm{~L}$ bioreactor with an initial $\mathrm{OD}_{600 \mathrm{~nm}}$ of 0.01 in a defined medium. Cultures were induced when cell concentration reached $50 \mathrm{~g} \mathrm{~L}^{-1}$ and cultivation occurred when cell concentration declined, and the collected samples were analyzed in HPLC. 
The culture induced with $30 \mathrm{~g} \mathrm{~L}^{-1}$ of lactose was the one that presented the highest production of acetate $\left(5.25 \mathrm{~g} \mathrm{~L}^{-1}\right)$, followed by $20 \mathrm{~g} \mathrm{~L}^{-1}\left(1.10 \mathrm{~g} \mathrm{~L}^{-1}\right)$ and lastly, $10 \mathrm{~g} \mathrm{~L}^{-1}$ $\left(0.96 \mathrm{~g} \mathrm{~L}^{-1}\right)$ (Figure 5). The only culture that was interrupted without the complete consumption of glucose was the cultivation induced with $30 \mathrm{~g} \mathrm{~L}^{-1}$ of lactose.

The maximum lactose concentration used was $30 \mathrm{~g} \mathrm{~L}^{-1}$, not inducing the culture comparable to what was found in experiments performed in shaker flasks. Maximum L-ASNase activity achieved in shaker flasks was $99.00 \mathrm{U} \mathrm{g}_{\text {cell }}{ }^{-1}$ compared to $41.68 \mathrm{U} \mathrm{g}_{\text {cell }}{ }^{-1}$ achieved in a bioreactor. The specific activity of the crude extract was $1.08 \mathrm{U} \mathrm{mg}^{-1}$, with a maximum volumetric activity of $43,954.79 \mathrm{U} \mathrm{L}^{-1}$ in the bioreactor. The cell concentration reached in the bioreactor was 27 -fold higher than in the shaker flasks.

Lactose induction optimization would require increasing the lactose concentration until it reaches the same level of induction as obtained when cultivation was carried out in shaker flasks. However, the increase in lactose concentration inside the bioreactor has a volume limitation, due to lactose low solubility. An increasing volume of the lactose solution would cause culture dilution, which may make the process unfeasible at an industrial level.

Kotzia and Labrou (2005) and Pourhossein and Korbekandi (2014) reported L-ASNase specific activity of $0.72 \mathrm{U} \mathrm{mg}^{-1}$ in the crude extract when working with the enzyme from Erwinia carotovora produced in E. coli $[57,66]$. A higher specific activity $\left(1.08 \mathrm{U} \mathrm{mg}^{-1}\right)$ was obtained in the present work. Chohan et al. (2018), obtained a volumetric activity of $20.13 \mathrm{U} \mathrm{L}^{-1}$ working with L-ASNase gene from Pyrobaculum calidifontis expressed in E. coli, lower than that found in the present study [42]. However, in a work published by Khushoo and collaborators (2005), the production of extracellular L-ASNase achieved the volumetric activity of $850,000 \mathrm{U} \mathrm{L}^{-1}$ in the extracellular medium, higher than that found in the present study [72].

\section{Conclusions}

This work carried out the production of the enzyme L-ASNase in recombinant Escherichia coli in a shaker and bioreactor using the defined medium and lactose as an inducer. The cell concentration was increased 27-fold when scaled up to a bioreactor, reaching about $70 \mathrm{~g} \mathrm{~L}^{-1}$ of dry weight and $43,954.79 \mathrm{U} \mathrm{L}^{-1}$ of volumetric activity. Despite the successful production of L-ASNase in a bioreactor, the increasing need for lactose concentration has become a problem during scaling, and new strategies are needed to optimize induction.

Author Contributions: Conceptualization, L.B., A.P.J., N.P. and P.O.M.; Data curation, T.B.; Formal analysis, T.B.; Funding acquisition, L.B. and P.O.M.; Investigation, T.B.; Methodology, L.B., N.P. and P.O.M.; Project administration, A.P.J. and P.O.M.; Resources, N.P. and P.O.M.; Software, P.O.M.; Supervision, A.P.J., N.P. and P.O.M.; Visualization, T.B.; Writing-original draft, T.B.; Writing-review and editing, L.B., M.F., A.P.J., N.P. and P.O.M. All authors have read and agreed to the published version of the manuscript.

Funding: This study was financed in part by the Coordenação de Aperfeiçoamento de Pessoal de Nível Superior-Brasil (CAPES)-FinanceCode 001 and the São Paulo Research Foundation (FAPESP)AwardNumber 2017/21819-9.

Conflicts of Interest: The authors declare that they have no conflict of interest.

\section{References}

1. Lassaletta Atienza, A. Leukemias. Acute lymphoblastic leukemia. Pediatr. Integr. 2016, 20, 380-389.

2. Emadi, A.; Law, J.Y. MSD Manuals. Available online: https://www.msdmanuals.com (accessed on 15 July 2020).

3. Quintanilla-Flores, D.L.; Flores-Caballero, M.Á.; Rodríguez-Gutiérrez, R.; Tamez-Pérez, H.E.; González-González, J.G. Acute Pancreatitis and Diabetic Ketoacidosis following L-Asparaginase/Prednisone Therapy in Acute Lymphoblastic Leukemia. Case Rep. Oncol. Med. 2014, 2014, 139169. [CrossRef] [PubMed]

4. Cachumba, J.J.M.; Antunes, F.A.F.; Peres, G.F.D.; Brumano, L.P.; Dos Santos, J.C.; Silva, S.S. Da Current applications and different approaches for microbial l-asparaginase production. Braz. J. Microbiol. J. Microbiol. 2016, 47, 77-85. [CrossRef] [PubMed]

5. Badoei-Dalfard, A. L-asparaginase production in the Pseudomonas pseudoalcaligenes strain JHS-71 isolated from Jooshan Hot-spring. Mol. Biol. Rescarch. Commun. 2016, 5, 1-10. 
6. Zyzak, D.V.; Sanders, R.A.; Stojanovic, M.; Tallmadge, D.H.; Eberhart, B.L.; Ewald, D.K.; Gruber, D.C.; Morsch, T.R.; Strothers, M.A.; Rizzi, G.P.; et al. Acrylamide formation mechanism in heated foods. J. Agric. Food Chem. 2003, 51, $4782-4787$. [CrossRef]

7. Lomelino, C.L.; Andring, J.T.; McKenna, R.; Kilberg, M.S. Asparagine synthetase: Function, structure, and role in disease. J. Biol. Chem. 2017, 292, 19952-19958. [CrossRef]

8. Silva, T.A.C.E.; Costa, I.M.; Biasoto, H.P.; Lima, G.M.; Silva, C.M.; Pessoa, A.; Monteiro, G. Critical overview of the main features and techniques used for the evaluation of the clinical applicability of L-asparaginase as a biopharmaceutical to treat blood cancer. Blood Rev. 2020, 107417. [CrossRef]

9. Doriya, K.; Kumar, D.S. Isolation and screening of L-asparaginase free of glutaminase and urease from fungal sp. 3 Biotech 2016, 6 , 1-10. [CrossRef]

10. Lima, G.M.; Effer, B.; Biasoto, H.P.; Feijoli, V.; Pessoa, A.; Palmisano, G.; Monteiro, G. Glycosylation of L-asparaginase from E. coli through yeast expression and site-directed mutagenesis. Biochem. Eng. J. 2020, 156, 107516. [CrossRef]

11. Woods, D.; Winchester, K.; Towerman, A.; Gettinger, K.; Carey, C.; Timmermann, K.; Langley, R.; Browne, E. From the Children's Oncology Group: Evidence-Based Recommendations for PEG-Asparaginase Nurse Monitoring, Hypersensitivity Reaction Management, and Patient/Family Education. J. Pediatr. Oncol. Nurs. 2017, 34, 387-396. [CrossRef]

12. Hunt, I. From gene to protein: A review of new and enabling technologies for multi-parallel protein expression. Protein Expr. Purif. 2005, 40, 1-22. [CrossRef] [PubMed]

13. Schimidell, W.; Lima, U.A.; Aquarone, E.; Borzani, W. Biotecnologia Industrial: Engenharia Quimica; Editora Edgard Blucher LTDA: São Paulo, Brazil, 2001.

14. Lee, S.Y. High cell-density culture of Escherichia coli. Trends Biotechnol. 1996, 14, 98-105. [CrossRef]

15. Tripathi, N.K.; Shrivastava, A. Recent Developments in Bioprocessing of Recombinant Proteins: Expression Hosts and Process Development. Front. Bioeng. Biotechnol. 2019, 7, 420. [CrossRef] [PubMed]

16. Baneyx, F. Recombinant protein expression in Escherichia coli. Curr. Opin. Biotechnol. 1999, 10, 411-421. [CrossRef]

17. Rosano, G.L.; Ceccarelli, E.A. Recombinant protein expression in Escherichia coli: Advances and challenges. Front. Microbiol. 2014, 5,1-17. [CrossRef]

18. Riesenberg, D.; Schulz, V.; Knorre, W.A.; Pohl, H.D.; Korz, D.J.; Sanders, E.A.; Roß, A.; Deckwer, W.D. High cell density cultivation of Escherichia coli at controlled specific growth rate. J. Biotechnol. 1991, 20, 17-28. [CrossRef]

19. Studier, F.W. Protein production by auto-induction in high density shaking cultures. Protein Expr. Purif. 2005, 41, 207-234. [CrossRef]

20. Santos, J.C.F. Cultivation of Escherichia coli BL21 (DE3) For Production of L-Asparaginase II. Master's Thesis, University of Sao Paulo, São Paulo, Brazil, 2017.

21. Babbal; Adivitiya; Mohanty, S.; Khasa, Y.P. Bioprocess optimization for the overproduction of catalytic domain of ubiquitin-like protease 1 (Ulp1) from S. cerevisiae in E. coli fed-batch culture. Enzyme Microb. Technol. 2019, 120, 98-109. [CrossRef]

22. Chua, L.H.; Tan, S.C.; Liew, M.W.O. Process intensification of core streptavidin production through high-cell-density cultivation of recombinant E. coli and a temperature-based refolding method. J. Biotechnol. 2018, 276-277, 34-41. [CrossRef]

23. Duan, X.; Zhang, X.; Shen, Z.; Su, E.; Zhao, L.; Pei, J. Efficient production of aggregation prone 4- $\alpha$-glucanotransferase by combined use of molecular chaperones and chemical chaperones in Escherichia coli. J. Biotechnol. 2019, 292, 68-75. [CrossRef]

24. Saha, A.; Acharya, B.N.; Priya, R.; Tripathi, N.K.; Shrivastava, A.; Rao, M.K.; Kesari, P.; Narwal, M.; Tomar, S.; Bhagyawant, S.S.; et al. Development of nsP2 protease based cell free high throughput screening assay for evaluation of inhibitors against emerging Chikungunya virus. Sci. Rep. 2018, 8, 10831. [CrossRef] [PubMed]

25. Bashir, H.; Ahmed, N.; Khan, M.A.; Zafar, A.U.; Tahir, S.; Khan, M.I.; Khan, F.; Husnain, T. Simple procedure applying lactose induction and one-step purification for high-yield production of rhCIFN. Biotechnol. Appl. Biochem. 2016, 63, 708-714. [CrossRef] [PubMed]

26. Kim, Y.S.; Karisa, N.; Jeon, W.Y.; Lee, H.; Kim, Y.; Ahn, J. High-level production of N-terminal pro-brain natriuretic peptide, as a calibrant of heart failure diagnosis, in Escherichia coli. Appl. Microbiol. Biotechnol. 2019, 103, 4779-4788. [CrossRef] [PubMed]

27. Tian, H.; Tang, L.; Wang, Y.; Wang, X.; Guan, L.; Zhang, J.; Wu, X.; Li, X. Lactose induction increases production of recombinant keratinocyte growth factor-2 in Escherichia coli. Int. J. Pept. Res. Ther. 2011, 17, 123-129. [CrossRef]

28. Drainas, C.; Kinghorn, J.R.; Pateman, J.A. Aspartic hydroxamate resistance and asparaginase regulation in the fungus Aspergillus nidulans. J. Gen. Microbiol. 1977, 98, 493-501. [CrossRef]

29. Ponce, E. Effect of growth rate reduction and genetic modifications on acetate accumulation and biomass yields in Escherichia coli. J. Biosci. Bioeng. 1999, 87, 775-780. [CrossRef]

30. Lozano Terol, G.; Gallego-Jara, J.; Sola Martínez, R.A.; Cánovas Díaz, M.; De Diego Puente, T. Engineering protein production by rationally choosing a carbon and nitrogen source using E. coli BL21 acetate metabolism knockout strains. Microb. Cell Fact. 2019, 18, 1-19. [CrossRef]

31. Luli, G.W.; Strohl, W.R. Comparison of growth, acetate production, and acetate inhibition of Escherichia coli strains in batch and fed-batch fermentations. Appl. Environ. Microbiol. 1990, 56, 1004-1011. [CrossRef]

32. Müller, J.; Beckers, M.; Mußmann, N.; Bongaerts, J.; Büchs, J. Elucidation of auxotrophic deficiencies of Bacillus pumilus DSM 18097 to develop a defined minimal medium. Microb. Cell Fact. 2018, 17, 1-17. [CrossRef] 
33. Jiao, L.; Chi, H.; Lu, Z.; Zhang, C.; Chia, S.R.; Show, P.L.; Tao, Y.; Lu, F. Characterization of a novel type I L-asparaginase from Acinetobacter soli and its ability to inhibit acrylamide formation in potato chips. J. Biosci. Bioeng. 2020, 129, 672-678. [CrossRef]

34. Mihooliya, K.N.; Nandal, J.; Kumari, A.; Nanda, S.; Verma, H.; Sahoo, D.K. Studies on efficient production of a novel l-asparaginase by a newly isolated Pseudomonas resinovorans IGS-131 and its heterologous expression in Escherichia coli. 3 Biotech 2020, 10, 1-11. [CrossRef] [PubMed]

35. Safary, A.; Moniri, R.; Hamzeh-Mivehroud, M.; Dastmalchi, S. Highly efficient novel recombinant L-asparaginase with no glutaminase activity from a new halo-thermotolerant Bacillus strain. BioImpacts 2019, 9, 15-23. [CrossRef]

36. Zhang, Y.; Li, D.; Li, Y. Expression and purification of L-asparaginase from Escherichia coli and the inhibitory effects of cyclic dipeptides. Nat. Prod. Res. 2017, 31, 2099-2106. [CrossRef] [PubMed]

37. Pokrovskaya, M.V.; Aleksandrova, S.S.; Pokrovsky, V.S.; Veselovsky, A.V.; Grishin, D.V.; Abakumova, O.Y.; Podobed, O.V.; Mishin, A.A.; Zhdanov, D.D.; Sokolov, N.N. Identification of Functional Regions in the Rhodospirillum rubrum L-Asparaginase by Site-Directed Mutagenesis. Mol. Biotechnol. 2015, 57, 251-264. [CrossRef] [PubMed]

38. Maqsood, B.; Basit, A.; Khurshid, M.; Bashir, Q. Characterization of a thermostable, allosteric L-asparaginase from Anoxybacillus flavithermus. Int. J. Biol. Macromol. 2020, 152, 584-592. [CrossRef]

39. Chohan, S.M.; Sajed, M.; Naeem, S.U.; Rashid, N. Heterologous gene expression and characterization of TK2246, a highly active and thermostable plant type L-asparaginase from Thermococcus kodakarensis. Int. J. Biol. Macromol. 2020, 147, 131-137. [CrossRef]

40. Farahat, M.G.; Amr, D.; Galal, A. Molecular cloning, structural modeling and characterization of a novel glutaminase-free L-asparaginase from Cobetia amphilecti AMI6. Int. J. Biol. Macromol. 2020, 143, 685-695. [CrossRef]

41. Aishwarya, S.S.; Selvarajan, E.; Iyappan, S.; Rajnish, K.N. Recombinant 1-Asparaginase II from Lactobacillus casei subsp. casei ATCC 393 and Its Anticancer Activity. Indian J. Microbiol. 2019, 59, 313-320. [CrossRef]

42. Chohan, S.M.; Rashid, N.; Sajed, M.; Imanaka, T. Pcal_0970: An extremely thermostable L-asparaginase from Pyrobaculum calidifontis with no detectable glutaminase activity. Folia Microbiol. 2018, 64, 313-320. [CrossRef]

43. Radha, R.; Arumugam, N.; Gummadi, S.N. Glutaminase free L-asparaginase from Vibrio cholerae: Heterologous expression, purification and biochemical characterization. Int. J. Biol. Macromol. 2018, 111, 129-138. [CrossRef]

44. Sindhu, R.; Manonmani, H.K. Expression and characterization of recombinant L-asparaginase from Pseudomonas fluorescens. Protein Expr. Purif. 2018, 143, 83-91. [CrossRef] [PubMed]

45. Farag, A.; Ataya, F.; Ali, H.; Hussein, A.; Saeed, H.; El-Sharkawy, A.; Embaby, A.; Soudan, H. Molecular cloning, structural modeling and production of recombinant Aspergillus terreus L. asparaginase in Escherichia coli. Int. J. Biol. Macromol. 2017, 106, 1041-1051. [CrossRef]

46. Ghasemi, A.; Asad, S.; Kabiri, M.; Dabirmanesh, B. Cloning and characterization of Halomonas elongata L-asparaginase, a promising chemotherapeutic agent. Appl. Microbiol. Biotechnol. 2017, 101, 7227-7238. [CrossRef] [PubMed]

47. Shi, R.; Liu, Y.; Mu, Q.; Jiang, Z.; Yang, S. Biochemical characterization of a novel L-asparaginase from Paenibacillus barengoltzii being suitable for acrylamide reduction in potato chips and mooncakes. Int. J. Biol. Macromol. 2017, 96, 93-99. [CrossRef]

48. Kebeish, R.; El-Sayed, A.; Fahmy, H.; Abdel-Ghany, A. Molecular cloning, biochemical characterization, and antitumor properties of a novel L-asparaginase from Synechococcus elongatus PCC6803. Biochemistry 2016, 81, 1173-1181. [CrossRef] [PubMed]

49. Santos, J.H.P.M.; Costa, I.M.; Molino, J.V.D.; Leite, M.S.M.; Pimenta, M.V.; Coutinho, J.A.P.; Pessoa, A., Jr.; Ventura, S.P.M.; Lopes, A.M.; Monteiro, G. Heterologous expression and purification of active L-asparaginase I of Saccharomyces cerevisiae in Escherichia coli host. Biotechnol. Prog. 2016, 33, 416-424. [CrossRef]

50. Costa, I.M.; Schultz, L.; De Araujo Bianchi Pedra, B.; Leite, M.S.M.; Farsky, S.H.P.; De Oliveira, M.A.; Pessoa, A.; Monteiro, G. Recombinant L-asparaginase 1 from Saccharomyces cerevisiae: An allosteric enzyme with antineoplastic activity. Sci. Rep. 2016, 6, 1-11. [CrossRef]

51. Labrou, N.E.; Muharram, M.M. Biochemical characterization and immobilization of Erwinia carotovora L-asparaginase in a microplate for high-throughput biosensing of L-asparagine. Enzyme Microb. Technol. 2016, 92, 86-93. [CrossRef]

52. Lee, S.J.; Lee, Y.; Park, G.H.; Umasuthan, N.; Heo, S.J.; de Zoysa, M.; Jung, W.K.; Lee, D.W.; Kim, H.; Kang, D.H.; et al. A newly identified glutaminase-free L-Asparaginase (L-ASPG86) from the marine bacterium Mesoflavibacter zeaxanthinifaciens. J. Microbiol. Biotechnol. 2016, 26, 1115-1123. [CrossRef]

53. Kim, S.K.; Min, W.K.; Park, Y.C.; Seo, J.H. Application of repeated aspartate tags to improving extracellular production of Escherichia coli 1-asparaginase isozyme II. Enzyme Microb. Technol. 2015, 79-80, 49-54. [CrossRef]

54. Kishore, V.; Nishita, K.P.; Manonmani, H.K. Cloning, expression and characterization of l-asparaginase from Pseudomonas fluorescens for large scale production in E. coli BL21. 3 Biotech 2015, 5, 975-981. [CrossRef] [PubMed]

55. Upadhyay, A.K.; Singh, A.; Mukherjee, K.J.; Panda, A.K. Refolding and purification of recombinant L-asparaginase from inclusion bodies of E. coli into active tetrameric protein. Front. Microbiol. 2014, 5, 1-11. [CrossRef] [PubMed]

56. Han, S.; Jung, J.; Park, W. Biochemical Characterization of L-Asparaginase in NaCl-Tolerant Staphylococcus sp. OJ82 Isolated from Fermented Seafood. J. Microbiol. Biotechnol. 2014, 24, 1096-1104. [CrossRef] [PubMed]

57. Pourhossein, M.; Korbekandi, H. Cloning, expression, purification and characterisation of Erwinia carotovora L-asparaginase in Escherichia coli. Adv. Biomed. Res. 2014, 3, 82. [CrossRef] [PubMed]

58. Roth, G.; Nunes, J.E.S.; Rosado, L.A.; Bizarro, C.V.; Volpato, G.; Nunes, C.P.; Renard, G.; Basso, L.A.; Santos, D.S.; Chies, J.M. Recombinant Erwinia carotovora l-asparaginase II production in Escherichia coli fed-batch cultures. Brazilian J. Chem. Eng. 2013, 30, 245-256. [CrossRef] 
59. Pokrovskii, V.S.; Pokrovskaya, M.V.; Aleksandrova, S.S.; Anrianov, R.M.; Zhdanov, D.D.; Osmel'yanyuk, N.M.; Treshchalina, E.M.; Sokolov, N.N. Physicochemical properties and antiproliferative activity of recombinant Yersinia pseudotuberculosis L-asparaginase. Appl. Biochem. Microbiol. 2013, 49, 18-22. [CrossRef]

60. Sidoruk, K.V.; Pokrovsky, V.S.; Borisova, A.A.; Omeljanuk, N.M.; Aleksandrova, S.S.; Pokrovskaya, M.V.; Gladilina, J.A.; Bogush, V.G.; Sokolov, N.N. Creation of a producent, optimization of expression, and purifi cation of recombinant Yersinia Pseudotuberculosis L-asparaginase. Bull. Exp. Biol. Med. 2011, 152, 219-223. [CrossRef]

61. Oza, V.P.; Parmar, P.P.; Patel, D.H.; Subramanian, R.B. Cloning, expression and characterization of l-asparaginase from Withania somnifera L. for large scale production. 3 Biotech 2011, 1, 21-26. [CrossRef]

62. Pokrovskaya, M.V.; Aleksandrova, S.S.; Pokrovsky, V.S.; Omeljanjuk, N.M.; Borisova, A.A.; Anisimova, N.Y.; Sokolov, N.N. Cloning, expression and characterization of the recombinant Yersinia pseudotuberculosis L-asparaginase. Protein Expr. Purif. 2012, 82, 150-154. [CrossRef]

63. Eisele, N.; Linke, D.; Bitzer, K.; Na'amnieh, S.; Nimtz, M.; Berger, R.G. The first characterized asparaginase from a basidiomycete, Flammulina velutipes. Bioresour. Technol. 2011, 102, 3316-3321. [CrossRef]

64. Cho, C.W.; Lee, H.J.; Chung, E.; Kim, K.M.; Heo, J.E.; Kim, J.I.; Chung, J.; Ma, Y.; Fukui, K.; Lee, D.W.; et al. Molecular characterization of the soybean L-asparaginase gene induced by low temperature stress. Mol. Cells 2007, 23, 280-286. [PubMed]

65. Jianhua, C.; Yujun, W.; Ruibo, J.; Min, W.; Wutong, W. Probing the antigenicity of E. coli L-asparaginase by mutational analysis. Mol. Biotechnol. 2006, 33, 57-65. [CrossRef] [PubMed]

66. Kotzia, G.A.; Labrou, N.E. Cloning, expression and characterisation of Erwinia carotovora L-asparaginase. J. Biotechnol. 2005, 119, 309-323. [CrossRef] [PubMed]

67. Krasotkina, J.; Borisova, A.A.; Gervaziev, Y.V.; Sokolov, N.N. One-step purification and kinetic properties of the recombinant 1-asparaginase from Erwinia carotovora. Biotechnol. Appl. Biochem. 2004, 39, 215. [CrossRef]

68. Wang, Y.; Qian, S.; Meng, G.; Zhang, S. Cloning and Expression of L-Asparaginase Gene in Escherichia coli. Appl. Biochem. Biotechnol. 2001, 95, 93-101. [CrossRef]

69. Harms, E.; Wehner, A.; Jennings, M.P.; Pugh, K.J.; Beacham, I.R.; Rohm, K.H. Construction of expression systems for Escherichia coli asparaginase II and two-step purification of the recombinant enzyme from periplasmic extracts. Protein Expr. Purif. 1991, 2, 144-150. [CrossRef]

70. Ramadhan, S.H.; Matsui, T.; Nakano, K.; Minami, H. High cell density cultivation of Pseudomonas putida strain HKT554 and its application for optically active sulfoxide production. Appl. Microbiol. Biotechnol. 2013, 97, 1903-1907. [CrossRef]

71. Lee, Y.L.; Chang, H.N. High Cell Density Culture of a Recombinant Escherichia coli Producing Penicillin Acylase in a Membrane Cell Recycle Fermentor. Biotechnol. Bioeng. 1990, 36, 330-337. [CrossRef]

72. Khushoo, A.; Pal, Y.; Mukherjee, K.J. Optimization of extracellular production of recombinant asparaginase in Escherichia coli in shake-flask and bioreactor. Appl. Microbiol. Biotechnol. 2005, 68, 189-197. [CrossRef]

73. Vélez, A.M.; da Silva, A.J.; Luperni Horta, A.C.; Sargo, C.R.; Campani, G.; Gonçalves Silva, G.; de Lima Camargo Giordano, R.; Zangirolami, T.C. High-throughput strategies for penicillin $\mathrm{G}$ acylase production in $\mathrm{r}$ E. coli fed-batch cultivations. BMC Biotechnol. 2014, 14, 6. [CrossRef]

74. Lim, H.K.; Lee, S.U.; Chung, S.I.; Jung, K.H.; Seo, J.H. Induction of the T7 promoter using lactose for production of recombinant plasminogen kringle 1-3 in Escherichia coli. J. Microbiol. Biotechnol. 2004, 14, 225-230. 